\title{
Consumer Preferences in the Content of Loyalty to the Yoghurt Brand
}

Ingrida Košičiarová, Zdenka Kádeková, Mária Holotová, L’ubica Kubicová, Kristína Predanocyová

Faculty of Economics and Management, Slovak University of Agriculture in Nitra, Slovakia

\begin{abstract}
The aim of submitted paper was to analyze customer preferences in the context of loyalty to the brand of selected food products in the segment of yoghurts. In order to achieve the mentioned aim, we used methods of survey, structured questionnaire (sample of 693 randomly chosen respondents) and blind test (sample of 100 respondents testing the four yoghurts -2 yoghurts of traditional brands and 2 yoghurts of private labels). For a deeper analysis of the obtained results, totally four hypotheses were set out and tested by using the statistical methods of Contingency table chi-square test, Pearson's chi-square test, Cramer's coefficient, Friedman test and Kolmogorov-Smirnov Test. The results of the survey proved that more than $30 \%$ of respondents consume yoghurts on a daily basis, $30 \%$ of respondents prefer to buy the yogurts of private labels, more than $64 \%$ of respondents consider themselves as loyal consumers and based on the package, the tested sample of private label yoghurt (sample A) would be purchased by $56 \%$ of respondents while the same sample of yoghurt (sample A) would be purchased for its taste just by $47 \%$ of respondents.
\end{abstract}

\section{Keywords}

Yoghurt, private label, traditional brand, consumer preference, loyalty.

Košičiarová, I., Kádeková, Z., Holotová, M., Kubicová, L. and Predanocyová, K. (2020) “Consumer Preferences in the Content of Loyalty to the Yoghurt Brand", AGRIS on-line Papers in Economics and Informatics, Vol. 12, No. 1, pp. 37-48. ISSN 1804-1930. DOI 10.7160/aol.2020.120104.

\section{Introduction}

In today's modern and globalized world, the consumers live in an increasingly competitive and dynamic market environment (Smutka et al., 2016, Polakevičová, 2015; Džupina et al., 2016; Mach et al., 2018; Balcarová et al., 2014; Kádek, 2014), where the brand by itself either loses its power or strengthens it. One of the primary objectives of the brand's existence is to establish a relationship with the consumer. The choice of the right brand is made through two crucial moments, namely by selecting the product in the store, where the customer decides which of the brands to buy; and by an additional decision at consumer's home, when the product of the given brand is used and then consumer realizes whether is satisfied with product or not (Animashaun et al., 2013; Alić et al., 2017).

Brands that win again in both of these critical cases gain a special place in the hearts and minds of consumers. The result can be the creation of so-called love brands, i.e. permanent even lifelong brand relationships with consumers (Das, 2019).
At a time when consumers are talking about brands, they often pay attention to only one of its aspects, either the name or the logo. However, in brand management, we are talking about an entire system that applies to the concept of the natural value of products and services defined by the name and set of characteristics (Kapferer, 2012; Hereźnia et al., 2018).

Brand management focuses on managing aspects of the company's offerings such as brand, logo, motto, character, product design or packaging to achieve the company's ultimate marketing goals. When we reconcile goals and marketing actions, we can talk about building a strong brand (Chernev, 2018; Urbancová and Hudáková, 2017).

Today, customers are surrounded by a large number of different brands. If consumers believe that most brands offer the same characteristics, that there are only minor quality differences between brands. This means that the consumer does not buy goods of just one particular brand, but rather purchases a group of acceptable brands. Purchasing decisions depend on criteria such as availability, price, or a particular 
product-specific offer, and hence the main criterion is not quality. As a result of this process, customer loyalty to a particular brand decreases significantly (Clow and Baack, 2008).

The brand contains basic visual elements such as logo, slogan or the name itself, on the basis of which consumers are able to identify the brand or company as well as to associate it with deeper values e.g. certain emotion, experience, story or relationship to lifestyle or status. The aim of the brand is to reach a potential target group of consumers in such a way that the brand becomes an integral and natural part of their being. To achieve this desired effect, it is necessary to use marketing tools designed to understand the needs of the market. (Banyár, 2017; Bartosik-Purgat, 2019).

A brand image is a multifunctional set of tangible and intangible elements that allows consumers to identify a product or service (Beverland, 2018). It has a complex and multidimensional nature and is the result of the consumer's mental process, respectively potential consumer receiving brand information. In this process, the individual gathers, evaluates, and combines brand-related information. The result is an image of a product, service or brand that plays an important role in its purchasing decisions (Singh and Duhan, 2016).

While the brand image is a tactical element that brings short-term results thanks to advertising and promotion experts; on the other hand, brand value is a strategic asset of the company that can underpin competitive advantage and long-term profitability and must therefore be closely monitored by the top management of the organization (Joachimsthaler and Aaker, 2009). In essence, brand value is an added value that affects each customers' purchasing decision and motivates them to purchase. It is demonstrated by knowing the brand name and responding to the product. It depends on customer loyalty, as it reflects the brand's identification with product quality (Jakubíková, 2009; Janoskova and Kliestikova, 2018).

The consumer is considered to be the end user of the product, unlike the one who buys goods or services but does not consume them himself (Bulanda et al., 2018a; Bulanda et al., 2018b; Pilar et al., 2018). Attracting customers is the primary goal of any business, as the customer creates demand for goods and services and is very likely to become a loyal consumer who becomes loyal to brand. Companies compete in particular by promoting and reducing prices to attract the largest customer base (Kenton, 2018; Světlík and Bulanda, 2019; Janková and Strbová, 2017; Kaliji et al., 2014).

The strategy of foreign, but also of domestic companies is to reach all groups of customers - to satisfy those customers, who are critical for low costs, but also those who prefer the purchase of high quality products. All designated requirements have to be satisfied by private label products, whose share in Europe, particularly in Slovakia, is constantly increasing (Košičiarová, et al., 2014). Private labels, very simply explained, represent a strategy for branding traditional brand products, but with a retailer's brand (whether by his own name or with a name which he owns) (Košičiarová and Nagyová, 2014). Private label brands have established their market in the United Stated and Europe in the past few decades. In their beginnings, consumers tended to perceive them just as a substitute or option to the traditional brands because of their white - black packs, location somewhere on the bottom shelves and low price. However, over the time, there have been several significant changes, which have made private labels acceptable alternatives for the purchase (Nagyová and Košičiarová, 2014). Development of private labels is now a global phenomenon, which brings both - advantages as well as disadvantages. The most apparent expansion of private labels, for the year 2013, was noticed in Switzerland with $37.7 \%$, unchanged in USA and the lowest one in China (0.4\%) (blog.euromonitor.com, 2014; IRi Growth delivered, 2013).

Submitted paper focuses on consumer preferences in the context of loyalty to the brand of selected food products in the dairy yoghurt segment. There have been investigated the consumers' preferences between the traditional brand or a private one in the segment of yoghurts, namely two traditionalbrand of yoghurts and two private-brand of yoghurts, which were tested in the form of a blank test.

Milk and dairy products, including yoghurt, rank among the commodities produced by food businesses and are thus integrated into the agro sector. Manufacture of dairy products is one of the key sectors within the food industry in the Czech Republic (Naglova et al., 2017) which is declared also by the fact, that dairy products are the export pillars of Czech agrarian foreign trade (Špička et al., 2015). Also in the Slovak Republic, the history of production and consumption of milk and dairy products has a very long tradition (Špička, 2015). In 1989, there was consumed $260 \mathrm{~kg}$ milk 
per person per year in Czechoslovakia and in that time there were 166 centrally managed dairies. After the Slovak Republic joined the EU, milk quota was allocated for milk production, which was set at the level of 1,061.6 mil.kg in 2009/2010 (Kubicová, 2012) and further increased to the level of 1,115.6 mil.kg in 2014/2015 (Kubicová, 2014); and after five years of a preparatory increase in their level, milk quotas disappeared on April $1^{\text {th }} 2015$ (Eurostat, 2015). Nowadays trend shows, that the of milk and dairy products consumption declines (Košičiarová et al., 2017).As presented in the part Results and discussion, the current consumption of milk and dairy products in the Slovak Republic is about $174 \mathrm{~kg}$ per person per year, which represents lower consumption by $20 \%$ compared to the recommended intake (Kubicová et al, 2019).

\section{Materials and methods}

The aim of the present paper was to analyze customer preferences in the context of loyalty to the brand of selected food products in the segment of dairy yoghurt. In order to achieve the above mentioned aim, there had been used the methods of survey, structured questionnaire and blind test. The questionnaire survey was conducted from April to May 2019 on a sample of 693 respondents chosen randomly, their basic characteristics are given in the Table 1. The sample can be considered as a representative on the $95 \%$ confidence level and $4 \%$ error margin, since $n \geq 600.25$. The blind test was then realized in May 2019 on a sample of 100 respondents, who were testing totally four yoghurts -2 yoghurts of traditional brands (Pribináčik as the sample $\mathrm{B}$ and Bánoveský jogurt as the sample C) and 2 yoghurts of private labels ( $\mathrm{K}$ classic as the sample A and Clever as the sample D).

The justification and selection of the above mentioned yoghurts can be justified by the fact that according to the results of several surveys (GfK Slovakia, 2010; TNS Slovakia, 2015), as well as according to the opinion of the most important retail chains operating in Slovakia, interest of Slovak consumers in private labels is constantly growing. Among the most frequently purchased private label categories can be clearly ranked milk and dairy products, juices, lemonades and mineral waters, respectively salty snacks (Košičiarová and Nagyová, 2014).

The questionnaire covered the entire territory of Slovakia, representing all regions. The questionnaire was conducted over the internet and consisted of 13 questions divided into two parts - the first part consisted of questions on the subject and the second part consisted of the classification questions. In order to ensure the representativeness of the results, we applied the random selection and geographic diversification of our respondents. The questionnaire was evaluated using the contingency tables prepared by Microsoft Office Excel, under which they were subsequently created the graphs.

\begin{tabular}{|c|c|c|}
\hline \multicolumn{2}{|c|}{ Characteristics of the respondents } & Number \\
\hline $\begin{array}{l}\text { Category } \\
\text { of respondents }\end{array}$ & $\begin{array}{l}\text { Male } \\
\text { Female }\end{array}$ & $\begin{array}{l}321 \\
372\end{array}$ \\
\hline $\begin{array}{l}\text { Age structure } \\
\text { of respondents }\end{array}$ & $\begin{array}{l}\text { Up to } 26 \text { years } \\
27 \text { - } 35 \text { years } \\
36 \text { - } 45 \text { years } \\
46-55 \text { years } \\
56 \text { years and more years }\end{array}$ & $\begin{array}{c}197 \\
245 \\
158 \\
67 \\
26\end{array}$ \\
\hline $\begin{array}{l}\text { Educational } \\
\text { structure of } \\
\text { respondents }\end{array}$ & $\begin{array}{l}\text { Primary education } \\
\text { Secondary education } \\
\text { without A level } \\
\text { Secondary education } \\
\text { Higher education I degree } \\
\text { Higher education II degree } \\
\text { Other }\end{array}$ & $\begin{array}{c}5 \\
49 \\
84 \\
227 \\
302 \\
26\end{array}$ \\
\hline $\begin{array}{l}\text { Economic activity } \\
\text { of respondents }\end{array}$ & $\begin{array}{l}\text { Student } \\
\text { On maternity leave } \\
\text { Unemployed } \\
\text { Employed } \\
\text { Retired } \\
\text { Other }\end{array}$ & $\begin{array}{c}282 \\
15 \\
21 \\
305 \\
4 \\
56\end{array}$ \\
\hline Region & $\begin{array}{l}\text { Banská Bystrica } \\
\text { Bratislava } \\
\text { Košice } \\
\text { Nitra } \\
\text { Prešov } \\
\text { Trenčín } \\
\text { Trnava } \\
\text { Žilina }\end{array}$ & $\begin{array}{c}99 \\
93 \\
58 \\
118 \\
64 \\
98 \\
96 \\
67\end{array}$ \\
\hline
\end{tabular}

The collected data were processed out with the use of Microsoft Excel and then evaluated in the statistical program XL Stat. The formulated hypotheses were tested by applying the statistical methods of Contingency table chi-square test, Pearson's chi-square test, Cramer's coefficient, Friedman test and Kolmogorov-Smirnov Test.

In hypothesis testing, if the p-value is lower than 
significant level, in case of XL Stat software, it is 0.05 , the null hypothesis is rejected, and the alternative hypothesis is confirmed (Witek, 2016).

For a deeper analysis of the research objectives, the following hypotheses were formulated:

Hypothesis 1: We assume that there is a relationship between the kind of preferred brand of purchased yogurts and the age category of respondents.

Hypothesis 2: We assume that there is a relationship between the kind of preferred brand of purchased yogurts and the gender of respondents.

Hypothesis 3: We assume that there is a statistically significant difference in the purchasing preferences of the product based on the packaging.

Hypothesis 4: We assume that there is a statistically significant difference in the evaluation of yogurt flavors.

\section{Results and discussion}

One of the most successful strategies of retailers is the sale of goods under the private label (Adamson, 2007). The purpose of this kind of sale is to attract new customers, which will later become loyal customers, and to build the image of the corresponding retail chain. In many cases, private labels are described and perceived as a global phenomenon (Herstein and Gamliel, 2004; Smith and Bashaw, 2009; Kakkos et al., 2015), which are constantly competing for the market position. Despite the fact that traditional brands are still dominant in today's competitive market, private labels are gradually progressing and tend to take over (Chimhundu, 2011; Ruiz-Real et al., 2016). Private label research shows that while 7 out of 10 buyers have already purchased a private label product in the US and considers it to be comparable to traditional brands or even higher quality (Park City Group, 2000). In the case of Europe, this share is even greater as the private label purchases in its individual countries increases year by year - actually, it has increased in 12 out of 19 European countries, and in 17 of them reached levels equal or greater than $30 \%$ (PLMA, 2018).

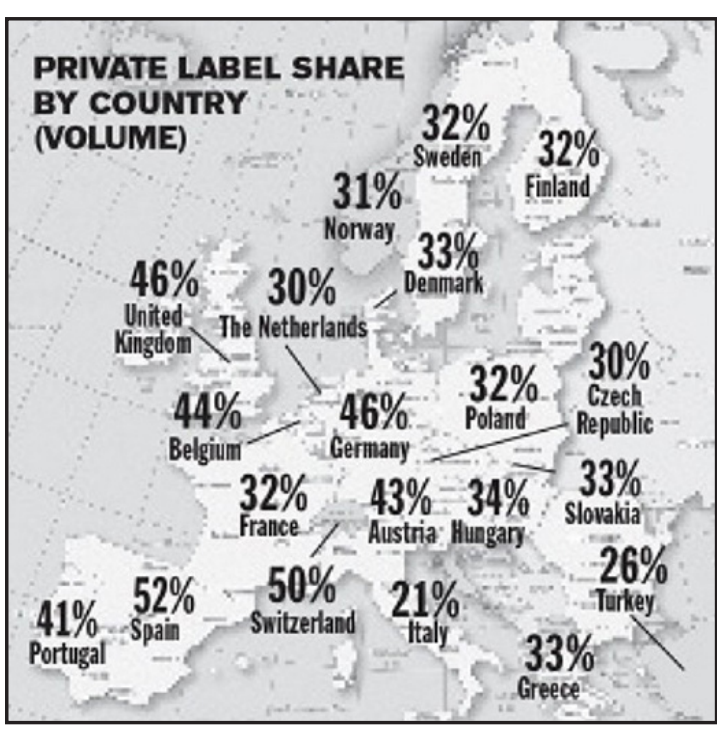

Source: PLMA. Industry news. Private label today (2018).

Figure 1: The share of private label chain purchases in household expenditures in 2018 (in \%).

Milk and dairy products represent one of the most elemental foods for all age categories of the population because of its biological component (Michaelidou, 2008; Maitah and Smutka, 2012; Pereira, 2014), but also a valuable food that have a beneficial effect on consumer health (Habánová, 2010; Dudriková et al., 2017; Kubicová et al., 2019). We classify them as functional foods that provide the consumer with a range of beneficial substances for immunity and vitality in addition to satiety. The benefits of this key nutritional food should motivate consumers to their daily consumption. In the Slovak Republic, the recommended dose of milk and dairy products is declared at $220 \mathrm{~kg}$ per person per year (Košičiarová et al., 2018). Figure 2 presents real consumption figures, which, unfortunately, have been lower than recommended over recent years - the last value meeting the recommended dose of consumption was recorded in 1990 .

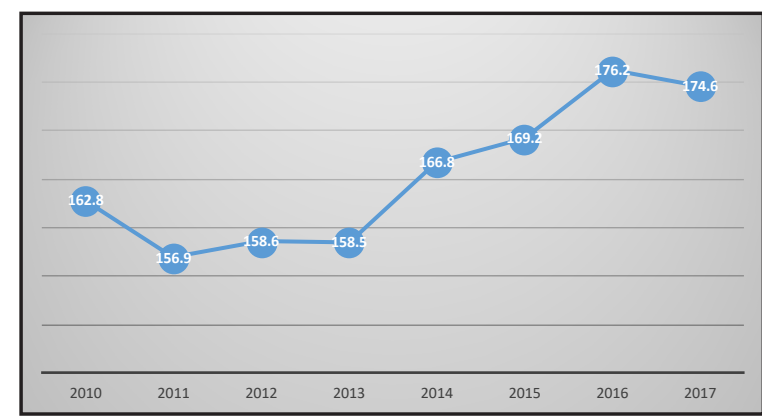

Source: SO SR

Figure 2: Development of milk and dairy products consumption in the Slovak Republic (per person in $\mathrm{kg}$ ). 


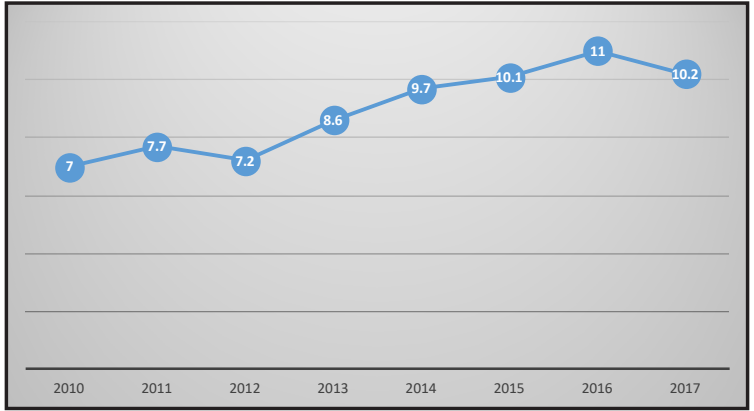

Source: NPPC

Figure 3: Average annual consumption of yoghurts in the Slovak Republic (per person in $\mathrm{kg}$ ).

Despite the consumption of milk and dairy products, which has generally declining trend in recent decades, the average consumption of yoghurt in kilograms per person has been on an upward trend almost annually. Figure 3 shows the development of this consumption, which has increased by $4 \mathrm{~kg}$ per person per year (by $57 \%$ ) over six years, which, despite the non-compliance with the recommended dose of dairy products, shows the increasing interest of yoghurts.

For this reason, milk yoghurts were the object of the study of submitted paper, where we focused on two samples of yoghurts sold under the traditional brand (samples B and C) and two samples of yoghurts sold under the private label (samples A and D).

As explained in the part Materials and methods, the choice of samples can be clearly explained by the increasing interest of Slovak consumers in the purchase of private label products, as well as by the fact that milk and dairy products are among the most frequently purchased private label categories in the food segment (Košičiarová, Nagyová, 2014). In terms of interest in the purchase of private label products of individual retail chains, respectively advantageous purchases and better customer orientation in stores, based on a survey conducted by TNS Slovakia in June 2012, the most popular private brands include brands by TESCO (49\% of respondents), COOP Jednota (44\% of respondents), Kaufland (32\% respondents) and Billa (23\%). According to the research, the products sold under private labels of COOP Jednota and TESCO are bought by women rather than men, and only $14 \%$ of respondents stated they do not buy any private label products (Fedorková, 2012).

As outlined above, research, questionnaire and blind test methods were chosen to investigate consumer preferences in the context of loyalty to the brand of selected food products in the segment of yoghurts. As can be seen from Table 1, a total of 693 respondents participated in the research, of which the majority were women (53.68\%), 27-35 years old respondents $(35.35 \%)$, employed $(44.01 \%)$ ), with higher secondary education $(43.58 \%)$ and respondents from the Nitra region (17.03\% of respondents).

The questionnaire survey focused mainly on their purchase and frequency of purchase, brand loyalty, brand preference (i.e. traditional brand or private label), as well as motives for purchase of individual types of brands. The survey was then supplemented by a blind test to examine the sensory properties of yogurts as well as the subsequent buying preference without knowing the real brand.

Research results point to many interesting findings - in terms of yogurt consumption, up to $33 \%$ of respondents (out of 677 respondents who eat yoghurts) consume yoghurts on a daily basis ( $18 \%$ once a day and $15 \%$ several times a day), up to $30 \%$ of respondents prefer to buy private label yoghurts and up to $64.21 \%$ of respondents consider themselves as loyal customers.

Consumer behavior does not only mean the behavior when purchasing a product or service, it is a sequence of several steps that the customer's mind goes through before buying something (Kumar, 2016). Consumers make this type of decision in average of 200 times a day, it is unlikely that they invest a lot of cognitive power in purchasing decisions (Wansink, 2010). Moreover, even if they are willing to think carefully about all their food choices, they have limited capacity to process all available information (Mawad et al., 2015). For this reason, they usually invest only a few seconds in purchasing decisions, paying attention only to some information (Mormann, Cerf, 2008).

In order to find out what leads the respondents to purchase a particular type of yoghurt brand, the questionnaire survey formulated questions about the motives for buying private labels and then the motives for buying traditional brands. Respondents were asked to assess individual motives on a scale of 1 to 5 (where 1 was the most and 5 was the least). As can be seen in Figure 4, the motives for buying either private yogurt label or traditional yogurt brands are essentially perceived the same. The most important motive for the purchase are recommendations from friends and acquaintances, the desire to try the product and then the promotion, price and visual site of the packaging. 


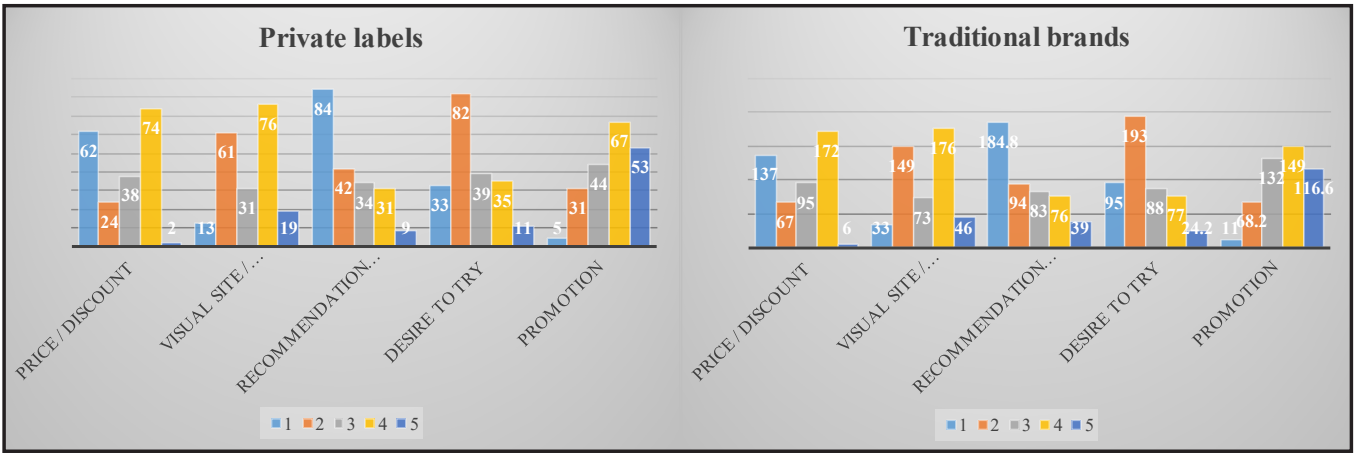

Source: results of own research

Figure 4: Motives for purchasing the yoghurts of private labels and traditional brands.

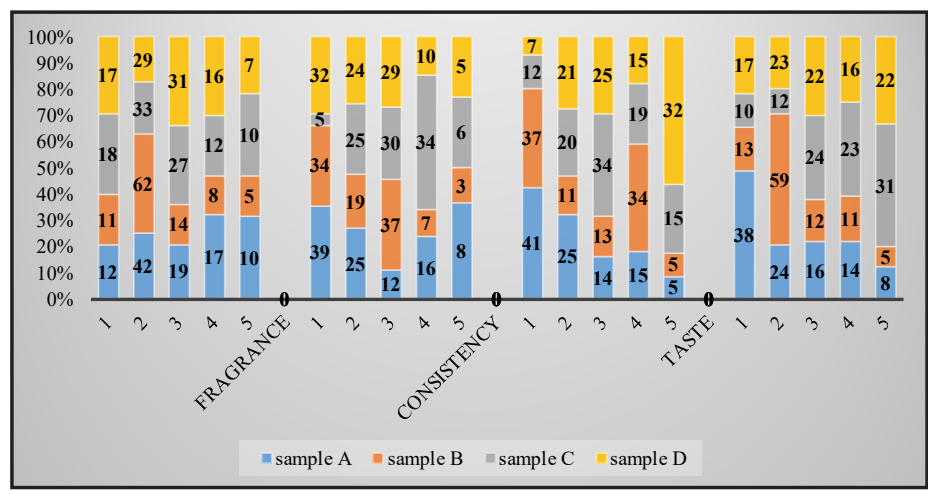

Source: results of own research

Figure 5: Evaluation of the sensory properties of the examined yogurt samples.

As we wanted to find out which of the examined yoghurt respondents prefer in their purchase (samples A to D, or none of them), which sample they would buy only on the basis of packaging and then on the basis of taste, in the questionnaire survey were also formulated these questions. Research results show that respondents prefer SampleA(private label sample) $34 \%$ of respondents, and sample B (traditional brand sample) 23\% of respondents. Based on the packaging they mainly buy sample A (private label sample) $56 \%$ of respondents, and sample B (traditional label sample) $32 \%$ of respondents. On the basis of taste, they would prefer to buy sample A (private label sample) $47 \%$ of respondents, and sample B (traditional brand sample) $24 \%$ of respondents.

In the case of evaluating the sensory properties of the examined yogurt samples as color, fragrance, consistency and taste can be said that respondents rated most positively samples A and B - one sample of a private yogurt label and one sample of a traditional yogurt brand. If we focused on the individual sensory properties, we would find that the best scent had Sample C- sample of the traditional yoghurt brand; while the sample A- the private yogurt label was then best rated for its consistency and taste (Figure 5).
An interesting finding of the research is that when the respondents had been asked to determine whether it was a traditional or private brand of yogurt based on the flavor, the most respondents did not identify it correctly - see Figure 6. The most respondents correctly identified only sample D, which was truly a private yogurt label. The remaining samples were identified incorrectly.

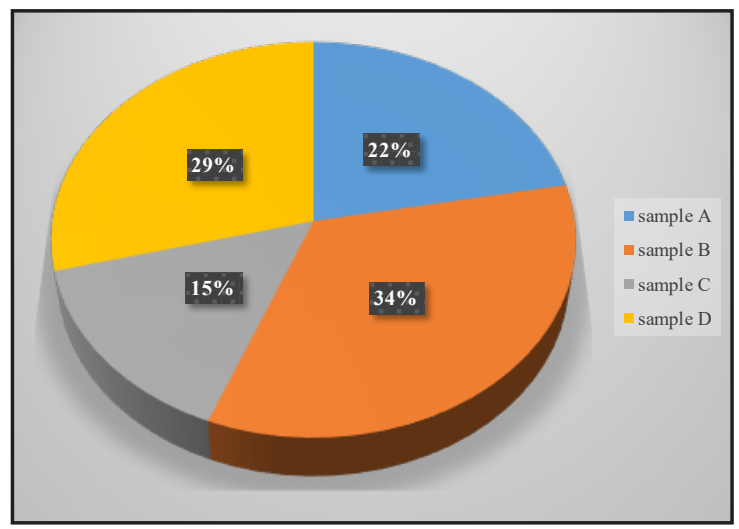

Source: results of own research

Figure 6: Identification of traditional brand and private label flavor of yoghurts.

As mentioned above, the survey also focused on evaluating a total of four statistical hypotheses, 
which were verified and statistically evaluated using the chosen statistical tests. Research shows that three of them have been confirmed, hypothesis 1,2 and 4 .

Hypothesis 1: We assume that there is a relationship between the kind of preferred brand of purchased yogurts and the age category of respondents.

\begin{tabular}{|l|c|c|c|}
\hline & \multicolumn{2}{|c|}{ Type of preferred brand } & \multirow{2}{*}{ Total } \\
\cline { 1 - 3 } Age category & $\begin{array}{c}\text { Private } \\
\text { label }\end{array}$ & $\begin{array}{c}\text { Traditional } \\
\text { brand }\end{array}$ & \\
\hline Up to 26 years & 31 & 166 & 197 \\
\hline 27-35 years & 76 & 169 & 245 \\
\hline 36-45 years & 67 & 91 & 158 \\
\hline 46-55 years & 18 & 49 & 67 \\
\hline 56 years and more & 8 & 18 & 26 \\
\hline Total & 200 & 493 & 693 \\
\hline
\end{tabular}

Source: Results of own research

Table 2: Chi square test for two independent sets for preferred yogurt brand type and respondent age.

Test characteristics $(\mathrm{TCH})-31.373$

Table value $(\mathrm{TH})-9.488$

\section{TCH $>$ TV}

\section{$H_{0}$ rejected, $H_{1}$ accepted}

Based on these calculations we accept the hypothesis $\mathrm{H}_{1}$, with $95 \%$ probability can be said that the type of preferred brand when buying yoghurt depends on the age category of the respondents. Since the dependence was found, we also examined the strength of the dependence. Based on the results of the Cramer coefficient, it can be said that this is a weak but statistically significant dependence (the Cramer coefficient was 0.0347).

Hypothesis 2: We assume that there is a relationship between the kind of preferred brand of purchased yogurts and the gender of respondents.

\begin{tabular}{|l|c|c|c|}
\hline & \multicolumn{2}{|c|}{ Category of respondents } & \multirow{2}{*}{ Total } \\
\cline { 1 - 2 } $\begin{array}{l}\text { Type of preferred } \\
\text { brand }\end{array}$ & Woman & Man & \\
\hline Private label & 145 & 55 & 200 \\
\hline Traditional brand & 270 & 223 & 493 \\
\hline Total & 372 & 321 & 693 \\
\hline
\end{tabular}

Source: Results of own research

Table 3: Chi square test for two independent sets for the preferred yogurt brand type and category of respondents .

Test characteristics $(\mathrm{TCH})-40.047$

Table value $(\mathrm{TV})-3.841$

$$
\text { TCH }>\text { TV }
$$

$H_{0}$ rejected, $H_{1}$ accepted
Based on these calculations, we accept the hypothesis $\mathrm{H} 1$, with $95 \%$ probability can be said that the type of preferred brand when buying yoghurt depends on the category of respondents. Since the dependence was found, we also examined the strength of the dependence. Based on the results of the Cramer coefficient, it can be said that it is a weak but statistically significant dependence (Cramer coefficient value was equal to 0.0118).

Hypothesis 3: We assume that there is a statistically significant difference in the purchasing preferences of the product based on the packaging.

\begin{tabular}{|l|c|}
\hline & Number of respondents \\
\hline sample A & 378 \\
\hline sample B & 221 \\
\hline sample C & 65 \\
\hline sample D & 14 \\
\hline Total & 677 \\
\hline Source: Results of own research \\
Table 4: Purchase of selected brand of yogurts \\
on the basis of packaging.
\end{tabular}

The result of the Kolmogorov-Smirnov test shows, that the value of the K-S test statistic (D) is 0.28759.; the p-value is 0.71235 . Based on the written we can say, that the data does not differ significantly from that which is normally distributed - we do not reject the null hypothesis

Hypothesis 4: We assume that there is a statistically significant difference in the evaluation of yogurt flavors.

\begin{tabular}{|l|c|}
\hline \multicolumn{2}{|c|}{ Average value } \\
\hline $\mathrm{A}$ & 0.05 \\
\hline $\mathrm{F}(\mathrm{TCH})$ & 11.36 \\
\hline $\mathrm{TV}$ & 0.022 \\
\hline
\end{tabular}

Source: Results of own research

Table 5: Friedman test for yogurt flavor evaluation.

Test characteristics $(\mathrm{TCH})-11.36$

Table value (TV) -0.022

$$
\begin{gathered}
\text { TCH }>\text { TV } \\
H_{0} \text { rejected, } H_{1} \text { accepted }
\end{gathered}
$$

Based on the results of Friedman's test, with 95\% probability can be said that there is at least one pair of yogurts with a statistically significant difference in appraisal of flavors. 


\section{Conclusion}

Despite the fact, that the overall consumption of milk and dairy products has been rather negative and declining in recent decades, the average consumption of yoghurt (in $\mathrm{kg}$ per capita) has increased almost annually (increased by $4 \mathrm{~kg}$ per year over the past six years). Mentioned is the reason why yoghurts, both traditional and private-brand yoghurts, have gradually become the object of our research. As we have pointed out in the introduction of the submitted paper, the results of our research can be used as a material for further research in this field as well as a guide to increase the attractiveness of yoghurt and thus increase its consumption by Slovak consumers. The results of our research point to many interesting findings - from the point of view of yogurt consumption, up to $33 \%$ of respondents consume yoghurts on a daily basis, up to $30 \%$ of them prefer in their purchase the private label yoghurts, up to $64 \%$ of respondents consider themselves as loyal customers, up to $34 \%$ of respondents prefer in their purchase exactly that sample of private label yoghurt, which was tested by us, also $23 \%$ of respondents prefer in their purchase that sample of traditional brand yoghurt, which was tested by us, and only on the basis of the package, as well as on the basis of taste, exactly $56 \%$ of respondents and $47 \%$ of respondents would buy the tested sample of private label product (sample A). Regarding the motives leading to the purchase of both yogurts (traditional brands and private labels), it can be concluded these motives are essentially the same - at first the recommendations from friends and acquaintances, the desire to try it and just then their promotion, respectively price and visual aspect of the packaging. Indeed, the results are surprising, as we would expect respondents to clearly prefer traditional brand yoghurts over private label yoghurts, but this has not been confirmed. On the basis of the above mentioned it can be said that the boundaries between traditional and private labels are gradually blurring and customers begin to realize that the private label products are a suitable alternative to their purchase. Possibilities of increasing the attractiveness of private label yoghurts (as we consider them as adequate alternatives to buying traditional brands of yoghurts) could be based in raising awareness about private labels and their real producers among Slovak consumers. In many cases, we find that Slovak consumers still hesitate to buy the private label products, because they do not have any experience with these products, respectively do not know their real producer. For this reason, the submitted paper can also serve as a tool to raise awareness of both the professional and general public, especially about the existence of private labels, their meaning, advantages and potential pitfalls.

\section{Acknowledgements}

The paper is a part of the research project GA SUA no. 8/2019 "Private labels as the alternative to purchase", solved at the Department of Marketing and Trade, Faculty of Economics and Management, Slovak University of Agriculture in Nitra.

\section{Corresponding authors}

Ing. Zdeňka Kádeková, Ph.D.

Department of Marketing and Trade, Faculty of Economics and Management

Slovak University of Agriculture in Nitra, Tr. A. Hlinku 2, 94976 Nitra, Slovakia

E-mail: zdenka.kadekova@uniag.sk

\section{References}

[1] Adamson, A. P. (2007) "Brand Simple: How the Best Brands Keep it Simple and Succeed", $1^{\text {st }}$ ed., Palgrave Macmillan, 256 p. ISBN-13: 978-1403984906.

[2] Alić, A., Agić, E. and Činjarević, M. (2017) "The Importance of Store Image and Retail Service Quality in Private Brand Image-Building", Entrepreneurial Business and Economics Review, Vol. 5, No. 1, pp. 27-42. E-ISSN 2353-8821, ISSN 2353-883X. DOI 10.15678/EBER.2017.050102.

[3] Animashaun, J. O., Williams, F. E. and Toye, A. A. (2013) "Towards Validating Moringa's Nutraceutical Benefits: An Examination of Consumers' Perspectives vis-a-vis Health Benefits Efficacy and Willingness to Pay“, Agris on-line Papers in Economics and Informatics, Vol. 5, No. 2, pp. 11-21. ISSN 1804-1930. 
[4] Balcarová, T., Pokorná, J. and Pilař, L. (2014) "The Influence of Children on the Parents Buying Behaviour: Food Purchase in the Czech Republic", Agris on-line Papers in Economics and Informatics, Vol. 6, No. 2, pp. 11-19. ISSN 1804-1930.

[5] Banyár, M. (2017) “Značka a logo: vizuálne prvky značky a ich význam v procese brandingu”, Zlín: Univerzita Tomáše Bati, 300 p. ISBN 978-80-745-4681-5. (In Czech).

[6] Bartosik-Purgat, M. (2019) "Digital Marketing Communication from the Perspective of Individual Consumers: A Cross-Country Comparison", Entrepreneurial Business and Economics Review, Vol. 7, No. 3, pp. 205-220. E-ISSN 2353-8821, ISSN 2353-883X. DOI 10.15678/EBER.2019.070311.

[7] Beverland, M. (2018) "Brand Management: Co-creating Meaningful Brands", California, SAGE Publications Ltd., 414 p. ISBN 978-14-739-5198-3.

[8] Bulanda, I., Džupina, M. and Franková, V. (2018a) "Consumer Assessment of Selected Food Commodities by Slovak Woman from Generation Y”, QUAERE 2018, Hradec Králové, pp. 174-184. ISBN 978-80-87952-26-9.

[9] Bulanda, I., Viteková, I., Koprda, T., Blahová, B. (2018b) "Slovak consumers from generation Y and their shopping behavior on discount portals", Proceedings of International Scientific Days 2018: "Towards Productive, Sustainable and Resilient Global Agriculture and Food Systems", Prague, Wolters Kluwer, pp. 275-287. ISBN 978-80-7598-180-6. DOI 10.15414/isd2018.s2-1.01

[10] Clow, K. and Baack, D. (2008) "Reklama, propagace a marketingová komunikace", Brno, Computer Press, 484 p. ISBN 978-80-251-1769-9. (In Czech).

[11] Das, G. (2019) "Does brand experience translate into brand commitment?: A mediated-moderation model of brand passion and perceived brand ethicality", Journal of Business Research, Vol. 95, pp. 479-490. ISSN 0148-2963. DOI 10.1016/j.jbusres.2018.05.026.

[12] Dudriková, E., Nagyová, M., Dičáková, Z. (2017) "Survival of Lactobacillus Bulgaricus and Bifidobacterium Animalis in Yoghurts Made From Commercial Starter Cultures During Refrigerated Storage", Potravinarstvo Slovak Journal of Food Sciences, Vol. 11, No. 1, pp. 597-601. ISSN 1337-0960. DOI 10.5219/758

[13] Džupina, M., Hodinková, D. and Kiková, H. (2016) "Spoločensky zodpovedné podnikanie ako zdroj hodnôt značky", Nitra, UKF, 84 p. ISBN 978-80-558-0991-5. (In Slovak).

[14] Džupina, M. and Janková, G. (2017) "Development of sustainable consumption through consumer education", 20 th International Scientific Conference „Economic and Social Development", Prague, 27-28 April, pp. 243-251. ISSN 1849-7535.

[15] Euromonitor (2014) "The New Face of Private Label: Global Market Trends to 2018“. [Online]. Available: $\quad \mathrm{http}: / /$ blog.euromonitor.com/2014/01/the-new-face-of-private-label-globalmarkettrends-to-2018.html [Accessed: 13 Sep. 2019].

[16] Eurostat (2015) "Milk and milk products - 30 years of quotas". [Online]. Available: http://ec.europa. eu/eurostat/statistics-explained/index.php/Milk_and_milk_products_-_30_years_of_quotas [Accessed: 20 Nov. 2019].

[17] Fedorková, J. (2012) "Najvýhodnejšie nákupy robíme v Kaufland“. [Online]. Available: http:// www.tns-global.sk/informacie-pre-vas/tlacove-spravy/najvyhodnejsie-nakupy-robime-vkauflande [Accessed: 15 Nov. 2019]. (In Slovak).

[18] Habánová, M., Lorková, M. and Kopčeková, J. (2010) “The consumption of acidophylus drinks and yogurts in selected population of pupils in years 2004 and 2008", Potravinarstvo Slovak Journal of Food Sciences, Vol. 4, No. 3, pp. 19-23. E-ISSN 1337-0960. DOI 10.5219/26.

[19] Herstein, R. and Gamliel, E. (2004) "An Investigation of Private Branding as a Global Phenomenon", Journal of Euromarketing, Vol. 13, No. 4, pp. 59-77. ISSN 0309-0566. DOI 10.1300/J037v13n04_04.

[20] Hereźniak, M., Florek, M. and Augustyn, A. (2018) "On Measuring Place Brand Effectiveness - between Theoretical Developments and Empirical Findings", Economics and Sociology, Vol. 11, No. 2, pp. 36-51. ISSN 2071-789X. DOI 10.14254/2071-789X.2018/11-2/3. 
[21] Chernev, A. (2018) "Strategic Brand Management", Chicago, Cerebellum Press, 206 p. ISBN 978-19-365-7238-0.

[22] Chimhundu, R. (2011) "Private Label Marketing Performance: An Analysis of Historical Trends Using Theories of Cumulative Change and Punctuated Equilibrium", International Journal of Business and Management, Vol. 6, No. 8, pp. 58-65. ISSN 1833-3850. DOI 10.5539/ijbm.v6n8p58.

[23] IRi Growth delivered. (2013) "Private Label: Balancing Quality and Value". [Online]. Available: http://www.iriworldwide.eu/Portals/0/articlepdfs/PrivateLabel_2013_Full\%20Report.pdf [Accessed: 10 Sep. 2019].

[24] Jakubíková, D. (2009) "Marketing v cestovnom ruchu", Prague, Grada Publishing, 288 p. ISBN 978-80-247-3247-3. (In Czech).

[25] Janková, G. and Strbová, E. (2017) "Educational aspect of advertising from perception of future marketing experts“, $20^{\text {th }}$ International Scientific Conference "Economic and Social Development", Prague, 27-28 April, pp. 598-609. ISSN 1849-7535.

[26] Janoskova,K. andKliestikova,J.(2018)"Analysisoftheimpactofselecteddeterminants on brandvalue", Journal of International Studies, Vol. 11, No. 1, pp. 152-162. E-ISSN 2306-3483, ISSN 2071-8330. DOI 10.14254/2071-8330.2018/11-1/11.

[27] Joachimsthaler, E. and Aaker, A. D. (2009) "Brand Leadership: Building Assets In an Information Economy”, New York, Free Press, 368 p. ISBN 978-14-391-7291-9.

[28] Kádek, P. (2014) "Súčasné dimenzie právnej zodpovednosti v medicíne a zdravotnictve”, Bratislava, Wolters Kluwer, 182 p. ISBN 978-80-8168-124-0. (In Slovak).

[29] Kakkos, N., Trivellas, P. and Sdrolias, L. (2015) "Identifying Drivers of Purchase Intention for Private Label Brands. Preliminary Evidence from Greek Cnsumers", Procedia - Social andBehavioralSciences, Vol.175,pp.522-528. ISSN 1877-0428.DOI 10.1016/j.sbspro.2015.01.1232.

[30] Kaliji, S. A., Mojaverian S. M., Amirnejad, H. and Canavari, M. (2019) "Factors Affecting Consumers' Dairy Products Preferences", Agris on-line Papers in Economics and Informatics, Vol. 11, Vo. 2, pp. 3-11. ISSN 1804-1930. DOI 10.7160/aol.2019.110201.

[31] Kapferer, J. N. (2012) "The New Strategic Brand Management: Advanced Insights and Strategic Thinking”, New York, Kogan Page Publishers, 512 p. ISBN 978-07-494-6515-5.

[32] Kenton, W. (2018) “Customer". [Online]. Available: https://www.investopedia.com/terms/c/ customer.asp [Accessed: 13 Sep. 2019].

[33] Košičiarová, I., Holienčinová, M. and Nagyová, L. (2014) "Knowledge and preference of private label products by Slovak consumer", Improving performance of agriculture and the economy: challenges for management and policy, MVD, 71 p. [Online]. Available: http://spu.fem.uniag.sk/ fem/mvd2014/proceedings/articles/Sedliakova.pdf [Accessed: 12 Sep. 2019].

[34] Košičiarová, I. and Nagyová, L. (2014) "Private label: the chance how to increase the consumer's interest in a proper retail chain", ICABR 2014, pp. 452-467. [Online]. Available: http://www.icabr. com/fullpapers/icabr2014.pdf [Accessed: 13 Sep. 2019].

[35] Košičiarová, I., Nagyová, L. and Holienčinová, M. (2017) "Consumer behaviour on Slovak yoghurt and fermented milk products market", Universitatis Agriculturaevet Silviculturae Mendelianae Brunensis, Vol. 65, No. 6, pp. 1967-1978. E -ISSN 2464-8310, ISSN 2464-8310. DOI 10.11118/actaun201765061967.

[36] Košičiarová, I., Nagyová, L'., Holienčinová, M., Kádeková, Z. and Rybanská, J. (2018) “Preference and perception of private label products and yoghurts - a case study of Slovak consumers with the age up to 30 years", International Scientific Days 2018: "Towards Productive, Sustainable and Resilient Global Agriculture and Food Systems", Prague, Wolters Kluwer, pp. 372-390. ISBN 978-80-7598-180-6. DOI 10.15414/isd2018.s2-1.08. 
[37] Kubicová, L. and Habánova, M. (2012) "Development of milk consumption and marketing analysis of its demand“", Potravinarstvo Slovak Journal of Food Sciences, Vol. 6, No. 4, pp. 66-72. E-ISSN 1337-0960. DOI 10.5219/236.

[38] Kubicová, L., Kádekova, Z. and Dobák, D. (2014) "Trends in consumption of milk and dairy products in Slovakia after EU accession", Polityki Europejskie, Finanse i Marketing, Vol. 12, No. 61, pp. 90-97. ISSN 2081-3430.

[39] Kubicová, L., Predanocyová, K. and Kádeková, Z. (2019) “The importance of milk and dairy products consumption as a part of rational nutrition", Potravinarstvo Slovak Journal of Food Sciences, Vol. 13, No. 1, pp. 234-243. E-ISSN 1337-0960. DOI 10.5219/1050.

[40] Kumar, R. (2016) "Consumer behavior. The role of Consumer Behavior in marketing strategy in the 3 marketing stimuli", San Francisco, GRIN Publishing, 20 p. ISBN 978-36-569-8858-8.

[41] Mach, J., Dvořák, M. and Hošková, P. (2018) "EU Milk and Dairy Market Changes and Impact of Globalisation Trends", Globalization and its socio-economic consequences (Part III.- Economic Progress in Post-Soviet Countries) 10.10.2018, Rajecke Teplice, Slovak Republic, Zilina, Slovakia, ZU-University of Zilina, pp. 1204-1212. ISSN 2454-0943.

[42] Maitah, M., Smutka, L. (2012) "Economic analysis of milk production and consumption in the Middle East adn North Africa“, Acta Universitatis Agriculturae et Silviculturae Mendelianae Brunensis, Vol. 60, pp. 245-254. E-ISSN 2464-8310, ISSN 2464-8310. DOI 10.11118/actaun201260040245.

[43] Mawad, F., Trías, M., Giménez, A., Maiche, A. and Ares, G. (2015) "Influence of cognitive style on information processing and selection of yogurt labels: Insights from an eye-tracking study", Food Research International, Vol. 74, pp. 1-9. ISSN 0963-9969. DOI 10.1016/j.foodres.2015.04.023.

[44] Michaelidou, A. M. (2008) "Factors influencing nutritional and health profile of milk and milk products“, Small Ruminant Research, Vol. 79, No. 1, pp. 42-50. ISSN 0921-4488. DOI 10.1016/j.smallrumres.2008.07.007.

[45] Mormann, M. and Cerf, M. (2008) "First attention then intention. Insights from computational neuroscience of vision", International Journal of Advertising, Vol. 27, pp. 381-398. E-ISSN 1759-3948, ISSN 0265-0487. DOI 10.2501/S0265048708080037.

[46] Naglova Z., Boberova B., Horakova T. and Smutka L. (2017) "Statistical analysis of factors inflencing the results of enter-prises in dairy industry", Agricultural Economics (AGRICECON), Vol. 63, No. 6, pp. 259-270. ISSN 0139-570X. DOI 10.17221/353/2015-AGRICECON.

[47] Nagyová, L'. and Košičiarová, I. (2014) "Privátne značky: fenomén označovania výrobkov 21. storočia na európskom trhu”, Nitra, SUA, 168 p. ISBN 978-80-552-1172-5. (In Slovak).

[48] Park City Group. (2000) "Private Label. A Store Brand Primer", 4 p. [Online]. Available: https://www.parkcitygroup.com/wp-content/uploads/WP_Private_Label_Primer.pdf [Accessed: 9 Sep. 2019].

[49] Pereira, P. C. (2014) "Milk nutritional composition and its role in human health“, Nutrition, Vol. 30, No. 6, pp. 619-627. ISSN 0899-9007. DOI 10.1016/j.nut.2013.10.011.

[50] Pilař, L., Kvasničková Stanislavská, K., Gresham, G., Poláková, J., Rojík, S. and Petkov, R. (2018) "Questionnaire vs. Social Media Analysis - Case Study of Organic Food", Agris online Papers in Economics and Informatics, Vol. 10, No. 3, pp. 93-101. ISSN 1804-1930. DOI 10.7160/aol.2018.100308.

[51] PLMA (2018) "Industry news. Private label today", [Online]. Available: https://www.plmainternational.com/industry-news/private-label-today [Accessed: 12 Sep. 2019].

[52] PLMA (2018) "Private label gains across Europe, climbing to all-time highs in seven countries", [Online]. Available: https://www.plmainternational.com/news-update [Accessed: 13 Sep. 2019]. 
[53] Polakevičová, I. (2015) "Application of transactional analysis in marketing research - models of the hierarchy of effects of marketing communication and structural analysis", Prohuman: vedecko-odborný internetový časopis - sociálna práca, psychológia, pedagogika, sociálna politika, zdravotníctvo, ošetrovatel'stvo, Vol. 7, No. 2, pp. 1-10. ISSN 1338-1415.

[54] Ruiz-Real, J. L., Gázquez-Abad, J. C., Esteban-Millat, I. and Martinez-Lopez, F. J. (2016) "Betting exclusively for private labels: Could it have negative consequences for retailers?", Spanish Journal of Marketing - ESIC, Vol. 11, 12 p. ISSN 2444-9709. DOI 10.1016/j.sjme.2016.12.004.

[55] Singh, A. and Duhan, P. (2016) "Managing Public Relations and Brand Image through Social Media“, Pensylvania, IGI Global, 353 p. ISBN 978-15-225-0332-3.

[56] Smith, R. K. and Bashaw, E. R. (2009) "Using Information Processing To Build A Private Label Brand In Big Emerging Markets", International Business \& Economics Research Journal , Vol. 8, No. 4, pp. 27-42. E-ISSN 2157-9393, ISSN 1535-0754. DOI 10.19030/iber.v8i4.3123.

[57] Smutka, L., Svatoš, M., Tomšík, K. and Sergienko, O. I. (2016) "Foreign trade in agricultural products in the Czech Republic", Agricultural Economics (AGRICECON), Vol. 62, No. 1, pp. 9-25. ISSN 0139-570X. DOI 10.17221/18/2015-AGRICECON.

[58] Statistics (2019) "Spotreba vybraných druhov potravín na 1 obyvatel'a", [Online]. Available: http://datacube.statistics.sk/\#!/view/sk/VBD_SLOVSTAT/ps2041rs/Spotreba\%20 vybran\%C3\%BDch\%20druhov\%20potrav\%C3\%ADn\%20na\%201\%20obyvate\%C4\%BEa\%20 \%5Bps2041rs\%5D [Accessed: 13 Sep. 2019]. (In Slovak).

[59] Světlík, J. and Bulanda, I. (2019) "Adolescents Perception of the Commercial Advertising in Slovakia", Economic and Social Development, Buenos Aires, pp. 201-209. ISSN 1949-7535.

[60] Špička, J. (2015) "The Efficiency Improvement of Central European Corporate Milk Processors in 2008-2013“, Agris on-line Papers in Economics and Informatics, Vol. 7, No. 4, pp. 175-188. ISSN 1804-1930.

[61] Špička, J., Smutka, L. and Selby, R. (2015) "Recent areas of innovation activities in the Czech dairy industry", Agricultural Ecnomics (AGRICECON), Vol. 6, No. 22, pp. 249-264. ISSN 0139-570X. DOI 10.17221/128/2014-AGRICECON.

[62] TASR (2010) "Prieskum: Predaj značkových tovarov si udržal postavenie aj v čase krízy“. [Online]. Available: http://www.edb.sk/sk/spravy/prieskum-predaj-znackovych-tovarov-si-udrzalpostavenie-aj-v-case-krizy-a2398.html [Accessed: 15 Nov. 2019]. (In Slovak).

[63] TNS (2015) "Oblúbenost' privátnych značiek na Slovensku rastie“. [Online]. Available: https://www.tns-global.sk/informacie-pre-vas/tlacove-spravy/oblubenost-privatnych-znaciek-naslovensku-rastie [Accessed: 15 Nov. 2019]. (In Slovak).

[64] Urbancová, H. and Hudáková, H. (2017) "Benefits of Employer Brand and the Supporting Trends", Economics and Sociology, Vol. 10, No. 4, pp. 41-50. ISSN 2071-789X. DOI 10.14254/2071-789X.2017/10-4/4.

[65] VEUPP (2018) "Mlieko", [Online]. Available: http://www.vuepp.sk/dokumenty/komodity/2018/ Mlieko_nov_18.pdf [Accessed: 12 Sep. 2019].

[66] Wansink, B. (2010) "From mindless eating to mindlessly eating better", Physiology \& Behavior, Vol. 100, No. 5, pp. 454-463. ISSN 0031-9384. DOI 10.1016/j.physbeh.2010.05.003.

[67] Witek, L. (2016) "Influence of Socio-demographic Characteristics of Consumers on Attitudes Towards Cause Related Marketing", Acta Universitatis Agriculturae et Silviculturae Mendelianae Brunensis, Vol. 64, No. 6, pp. 2173-2182. E-ISSN 2464-8310, ISSN 1211-8516. DOI 10.11118/actaun201664062173. 